\title{
Kanuni Dönemi İstanbul'unda Tutsaklıktan Hekimliğe Bir Yolculuk
}

\author{
Şaziye Dinçer Bahadır \\ Kırşehir Ahi Evran Üniversitesi, Türk Dili ve Edebiyatı Bölümü, Kırşehir \\ saziyedincer35@gmail.com \\ ORCID ID: https://orcid.org/0000-0002-8927-2672
}

\begin{tabular}{llll}
\multicolumn{4}{c}{ Derleme } \\
\hline Geliş Tarihi: & 07.04 .2018 & Revize Tarihi: & 12.06.2018
\end{tabular}

\section{Atıf Bilgisi}

Dinçer Bahadır, Ş. (2018). Kanuni Dönemi İstanbul'unda Tutsaklıktan Hekimliğe Bir Yolculuk, Ahi Evran Üniversitesi Sosyal Bilimler Enstitüsü Dergisi, 4(1), 75-86. Doi: 10.31592/aeusbed.413485

ÖZ

Fuat Carım tarafından kültürümüze kazandırılan bu eser, Kanuni döneminde tutsak olarak İstanbul'a getirilen bir kişinin başından geçen olayları barındırmaktadır. Seyahat, dünden bugüne çeşitli güzellikleri ve birçok bilinmeyeni göstererek farklı bir dünyanın kapısını bizlere aralamıştır. Gitmek isteyip gidemediğimiz yerleri bu sayede okuyarak da olsa gezmiş gibi oluruz ya da üstünkörü gezdiğimiz yerler hakkında bilmediklerimizi öğreniriz. Bunun yanında verilen kimi bilgiler de o güne dair tarihî ve toplumsal değerlere ulaşmamızı sağlar. Eseri dileyen tarihî bir roman, dileyen bir tababet kitabı, dileyen bir hatırat, dileyen seyahatname olarak da okuyabilir. Kısacası seyahat edebiyatının pek çok eseri gibi bu kitap da farklı zevklere ve farklı meşreplere, farklı ilgilere hitap edebilir. Çalışmamız eserin bütününü değil hekimlikle, tedavi ile ilgili söylenenleri içerir. Hastalıkları teşhis ve tedavi yöntemleriyle ilgili verilen örnekler, kaynaklardaki bilgilerle karşılaştıııldığında verilen bilgilerin tutarlı olup olmadığı görülecektir. Hastalık, teşhis, tedavi gibi sağlık hakkında öğrendiklerimiz yalnızca tıp tarihinin değil sosyal tarihin de konusudur. Belki de bu seyahat hatıralarının bize bir kez daha gösterdiği husus budur.

Anahtar Kelimeler: Pedro, seyahat, Osmanlıda hekimlik, teşhiş ve tedavi.

\section{A Journey From Captivity to Medicine in İstanbul in the Era of Suleiman The Magnificent}

\section{ABSTRACT}

This piece brought in our culture by Fuat Carım describes the events a person, who had been taken to Istanbul as a captive in the era of Suleiman the Magnificent, experienced. The journey has opened us the door of a different world by showing diverse beauties from past to the present and many unknowns. By this way, at least by reading, we are as if we go around the places we want to visit but cannot; or we learn the unknowns about the places we visited superficially. In addition, certain information offered enables us to reach the historical and social values referred to that time. One body can read the piece as a historical novel, another as a medicine book, anyone else as memoirs, and another as travel book. In short, this book, like other many travel books, may appeal to various tastes, temperaments, and interests. The present study involves those mentioned about medicine and treatment, but not the whole piece. It can be detected whether the information offered is consistent or not, as the examples given about the diagnosis and treatment methods of illnesses are compared to the information in sources. Not only the concepts that we learn about healt, such as disease, diagnosis and ttreatment, are the subjects of medical history, but also they are in the scope of the social history. Maybe this issue is the one that those travel memories show us once more.

Keywords: Pedro, journey, medicine in the Ottoman Empire, diagnosis and treatment.

\section{Giriş}

Seyahatin Batı düşüncesindeki değişimde oynadığı rolün altını çizen Paul Hazard, klasik çağın durgunluk ve mevcut durumu muhafaza etme anlamına geldiğini söylemiştir. Klasik devrin kapanması, rönesans, reform gibi büyük maceraların sona ermesiyle beraber Avrupalı için seyahat hayatın bir parçası olmuştur. Doğal olarak, seyahat eden insan bir yığın yeni şey görerek öğrenmiş, bunları başkalarına da aktarmıştır. "Sonsuz sahaları içine alan bir seyahat edebiyatı bilgin kişilerin yazdlklarl eserlerden müze kataloglarına ve aşk hikâyelerine kadar en değissik mevzuları ihtiva ediyordu. Bu bazan âlimane bilgi ve dolu ağır bir deneme, bazan bir psikoloji kitabl, düpedüz bir roman yahut bütün bunların bir karışımı oluyordu. Kimi bunları övüyor kimi de yeriyordu. Ama övenler de yerenler de seyahat edebiyatının işgal ettiği yerin ehemmiyetini ve ondan vazgeçilemeyeceğini belirttiler. Bu edebiyatın genişleyip serpilmesine yol açan temayüller aynı zamanda rehber ve menzil kitaplarının da yazılmasını da gerektirdi." (Hazard, 1999, s.23-24). 
Seyahat edebiyatı menzil kitaplarının yazılmasına kadar uzanmıştı uzanmasına ama seyahat henüz güzelliğin peşinde bir yolculuk değildir. Hazard'ın aşağıda işaret ettiği anlamı taşımaktadır.

"Seyahat: o henüz baş döndüren o güzellikleri arama, çeşitli ülkelerin değişik semalar altında herbirine ait his ve intibaları kaydetme anlamına gelmiyordu. O günlerde seyahat örf ve âdetleri, normlarl, felsefeleri, dinleri karşılaştırmak ve bir izafiyet kavramına ulaşmak, münakaşa, şüphe etmek demekti. Bilinmeyenleri bulup göstermek için dünyayı köşe-bucak dolaşanlar arasında birden fazla serbest fikirli kişi vardl." (Hazard,1999, s.44).

İşte o serbest fikirli kişilerden biridir, ele aldığımız eserin anlatıcısı Pedro. Onun anlattıkları, seyahat edebiyatının iyi bir numunesidir. Elbette örf, âdet, din gibi konular yanında çalışmamızın esas ilgi alanı olan hastalık, hekimlik ve tedavi konusunda da bilgiler vermektedir.

Dünden bugüne tedavi yöntemleri değişmiş olsa da sağlıkla olan imtihanımız değişmemiştir. Hastalanan her kişi, şifa ararken sağlıklı olanlar da hastalıklardan korunmak için çaba harcamışlardır. $\mathrm{Bu}$ nedenle tabiplik mesleği, insanlık tarihi kadar eskidir. "Bizden önce de bu hastalıklar var mıdı? Tedavi yöntemleri nasıldı?" sorularını sorduğumuzda geçmişin ayrıntılarına doğru yol alırız. Bu arayışta bize çoğunlukla tıp tarihi kitapları ve tıp yazmaları yardımcı olur. Osman Şevki Uludağ da özellikle ilk devirlerde yazılan ve bir kısmı devrimize intikal etmiş olan tıp kitaplarını birer birer ele alarak zamanın hekimliğini bunlardan anlamaya çalışmanın noksan da olsa tek bir çare olduğunu ve tutulacak başka yolun bulunmadığını belirtir (Uludağ, 2010). Örneğin kadın ve çocuk hastalıkları ile ilgili bilgi almak istediğimizde Şaban Şifâî ${ }^{1}$ ve Gevrekzâde Hâfiz Hasan'ın ${ }^{2}$ eserlerinden faydalanabiliriz.

Tıp tarihi kitapları ve tıp yazmalarının yanı sıra hatıralarda geçen bazı bilgiler de son derece önemlidir; Lady Montagu'nun hatıralarından çiçek aşısı ile ilgili bilgileri alırız (Montagu, 1998). Şair Leyla Saz'ın hatıralarından haremde tedavi ile ilgili bazı ayrıntıları öğrenebiliriz (Borak, 2004). Çalışmamızın konusu olan eser de böyle bir deneyim sonucu oluşturulmuştur. Fuad Carım'ın İspanya elçisiyken kütüphanede rastlayıp dilimize kazandırdığı bu kitap, Kanuni Sultan Süleyman dönemine ait çok değerli bilgileri içerisinde barındırmaktadır.

\section{Eser Hakkında}

Fuat Carım, kitapla ilgili olarak şu açıklamayı yapmıştır. "Eser 1557 yılında kaleme alınmış, iki suretlik nüsha asırlarca Madrid Üniversitesi'nin arşivleri arasında uyuyakalmış, tam 348 yıl geçtikten sonra, Zaragoza Üniversitesi'nin ünlü profesörlerinden Dr. Manuel Serranoy Sanz tarafindan keşfedilerek yayınlanmıştır. Türkiye Seyahati adıyla yayınlanan bu eser kimindir? Belli değil. Her ne kadar, üslub benzerliğinden ötürü, o devrin tanınmıs yazarlarından Cristol de Villanon'a isnad edenler varsa da, gene, belli değil demek gerekir. Neden? Çünkü okumak ve işitmekle ögrenilen bilgilere dayanarak yazılabilecek eserlerden değildir. Ancak ve ancak, anlatılan olayları bizzat görüp yaşamış bir kimsenin eseri olabilir. Dört yüz yıl önce tutsak düşen, bilgili ve açık düşünceli bir yabancinın İstanbul'da geçirdiklerini ve gördüklerini anlatan bu eser, Türkiye Tarihi bakımından, çok kıymetlidir. Kitap, güzel sahneler, tatlı anlatışlar, yerinde tahliller, ince alaylar, ilgilendirici ve aydınlatıcı bilgilerle doludur. Yazılanların arasında, en meşhur seyahatnamelerde bile eksik olmayan oransızlıklardan hiç birine rastlanmaz. Esasen, seyahatnameden ziyade, kitaba hatırat demek, daha uygun düşer." (Carım, 1964, s.5-7).

Fuat Carım tarafından önce Fransızcaya çevirtilen kitap, 1964’te Türkçeye çevrilmiştir. Carım, bu çeviride kitabın birinci bölümünden bazı kısımları ve ikinci bölümünün tamamını çevirmiştir. Kitap, daha sonra ikinci kez 'Türkiye'nin Dört Yılı: 1552-1556' adıyla A. Kurutoğlu tarafindan seçmeler hâlinde kısmen çevrilerek yayınlanmıştır (Önalp, 1990). Yeliz Demirören tarafından da 'Türkiye Seyahati Kanuni Sultan Süleyman Devrinde İstanbul (1557 yılında bir el yazmas1)' adıyla 2011'de yayınlanmıştır.

\footnotetext{
${ }^{1}$ Şaban Şifâiı’nin XVII. yüzyılda kaleme aldığı tıp tarihinde kadın ve çocuk hastalıklarını konu edinen ilk önemli eser, Tedbîrü'l-Mevlûd'dur.

${ }^{2}$ Gevrekzâde Hâfız Hasan Efendi’nin XVIII. yüzyılda kaleme aldığı tıp tarihinde kadın ve çocuk hastalıklarını konu edinen ikinci önemli eser, Netîcetü'l-Fikriyye fî Tedbîri Velâdeti'l-Bikriyye'dir.
} 
Carım, biri Osmanlı İmparatorlarının tarihçesi diğeri de Rodos Şövalyelerine dair bilgiler olmak üzere kitabın iki ekinin daha olduğunu belirtir (Carım, 1964). Çalışmamıza konu olan kitap, iki bölümden oluşur. Birinci bölümde tutsak olan Pedro'nun başından geçenler, ikinci bölümde Türkiye'nin o dönemdeki teşkilatı ve İstanbul halkının âdetleri anlatılır. Kitapta özellikle birinci bölümde yer alan başlıklar, Carım tarafından eklenmiştir. Parantez içindeki bilgiler de yine Carım'a ait olan açıklamalardır.

Kitap üç kişi (Pedro de Urdemalas, Juan de Voto a Dios ve Matalas Callando) arasında geçen diyaloglardan oluşur. Yazar, yani kitabın gerçek yazarı olan kişi, eserini 1 Mart 1557 tarihli ön sözle Şarlken'in oğlu ikinci Flip'e takdim ve ithaf etmiştir. "Haşmetmeabınızın, sırf mukaddes Katolik dinini korumak ve yaymak amacıyla yeryüzünde olup bitenleri ögrrenmek ve bunların künhüne varmak arzusunu beslediğinizi biliyorum. Ve güttüğ̈̈nüz bu yüksek amacın tahakkukuna en çetin engeli teşkil edenin Ulu-Türk olduğunu da öğrenmiş bulunuyorum. İşte, bu yönden haşmetmeabınızı aydınlatabilmek için, başlıca düşmanınızın hükümetini, gücünü, yaşayışını, âdetlerini be bedbaht tutsakların sürdükleri hayatı, bir konuşma şeklinde, belirterek sunmaya karar verdim." (Carım, 2002, 8-9). Yazarın metni diyalog üzerine kurması, metnin kolayca okunmasını sağlamış böylelikle okuyucuların aklına gelebilecek kimi sorular da cevapsız kalmamıştır.

Pedro adı verilen kişi Kanuni döneminde Sinan Paşa komutasındaki donanmaya esir düşüp İstanbul'a getirilmiş ve burada şahit olduğu olayları diyaloglarda nakletmiştir. Pedro'nun sağlık ile ilgili uygulamalarla söyledikleri tarihî kaynakların da doğruladığı bilgilerdir.

Her ne kadar ele aldığımız eser, Hazard'ın söylediği o "büyük değişmeden” önce kaleme alınmış olsa da, onun altını çizdiği o muazzam seyahat edebiyatının bir parçası olduğu kuşku götürmez. Eseri dileyen tarihî bir roman, dileyen bir tababet kitabı, dileyen bir hatırat, dileyen seyahatname olarak da okuyabilir. Kısacası seyahat edebiyatının pek çok eseri gibi bu kitap da farklı zevklere ve farklı meşreplere, farklı ilgilere hitap edebilmektedir. Çalışmamız eserin bütününü değil hekimlikle, tedavi ile ilgili söylenenleri ele almaktadır. Berberlerle ilgili söylenenler de yine hekimlikle ilgilidir, zira eski devrin berberleri zaman zaman cerrah, zaman zaman dişçidir.

\section{Pedro'nun Esaretten Kurtuluşu ve Hekimliği Öğrenmesi}

Sarı, hekimliğin Osmanlı döneminde üzerinde önemle durulmuş bir alan olduğunu ve bununla ilgili resmî evraklarda birçok bilgiye rastlanabileceğini belirtir. Saray hekimliğine atananların birçoğunun darüşşifa hekimlerinden ve Süleymaniye Medresesi'nden mezun olanların arasından seçildiğini, atamalarda ise liyakate dikkat edildiğini bildirir. Darüşşifalara hekim tayininde iyi ve tecrübeli hekimden beklenen özellikleri şu şekilde sıralar. "Teşhis ve tedavi sırasında dört humor (unsur) teorisini uygulamakta tecrübeli olmall, hasta mizacını belirleme ve ona göre ilaçlarını vermede ustalaşmuş, teoriyi pratiğe, pratikten öğrendiklerini tecrübesine katan, diğer bilimlere de hakim vb." (Sarı'dan akt., Aydın, 2006, s.195).

Pedro, her ne kadar bir tıp eğitiminden geçmeden sadece edinmiş olduğu bir tıp kitabını okuyarak Sinan Paşa'nın hekimi olmuş olsa da bir istisna olarak değerlendirilmelidir. Nitekim Şehsuvaroğlu, hekimlik temini konusunda üç yol olduğunu belirtmiştir. Bunlardan ilki, ülke içinde yetişen hekimler, ikincisi Mısır, Suriye, İran, Irak gibi Doğu merkezlerinde yetişen hekimler, üçüncüsü ise Avrupa'da yetişerek ülkeye gelen Hristiyan ve Yahudi hekimlerdir (Şehsuvaroğlu, Demirhan ve Güreşsever, 1984). Pedro'nun esaretten kurtulup hekimliğe geçişi şu şekilde olmuştur.

"Kürek kısmına ayrılmaktan kurtulmak için, Müslüman olmuş yaşlı bir tutsağın verdiği öğ̈̈de uyarak, hekimim, dedim. Bunu, biraz mürekkep yalamış olmaklı̆̆ıma güvenerek söyledim. Cerrah misin, diye, sordular. Hayır deyince, az kalsin partiyi kaybediyordum. Bereket versin lafa, sözü geçen kaptanlardan Durmuş Reis karıştı, Cenevizli dönme Durmuş Reis. "İdrar ve nabız hekimidir, cerrahtan daha faydalıdır", dedi. Kürekten işte bu suretle kurtuldum." (Carım, 1964, s.11).

"Daha yolda iken, gemide elime bir tıp kitabı geçti. Bu kitapta öğrendiklerimin dişında hiçbir şeyi tatbike girişmedim. Başlangıçta, yanı başımda hasta düşen tutsakları tedaviye koyuldum. Bu denemelerimden, memnunluk verici sonuçlar elde ettim. Bunu görünce, kuvvetli olan hafizamin yardımıyla, kitabı baştan aşağı ezberledim. Sonraları, karşılaştı̆̆ım hekimlere aklımda tuttuklarımı 
tekrarladığım zaman, çok şeyler bildiğimi sanarlardı. Ve anlattı̆̆ım gibi, hekimlik sanatını ü̧̈ ay içinde ögrenmiş oldum." (Carım, 1964, s.14).

Pedro'nun, anlatmış olduğu hatıratı boyunca Yahudi hekimlerle bir çekişme içerisinde oluşu dikkat çeken bir özelliktir.

"Bir gün paşayı hekimlerin verdikleri bir şurubu içmek üzereyken gördüm. Zehirli bir şey olduğunu hekimlerin önünde ispat edebileceğimi söyleyerek, bunu almaktan vazgeçmesini tavsiye ettim. Çok ürktü ve derhal hekimleri çağırttı... Paşanın karnına yel dolduğunu şurubun da soğuk olduğu için karnında yele döneceğini nitekim sütün de zararlı olduğunu çünkü süt, ateşte kaynayınca nasil köpürüyorsa, midenin hararetiyle de aynı şekilde köpüreceğini, öğrenebildiğim yarım yamalak bir Türkçeyle söyledim. Sözlerimin toplantıda bulunan Türklerin üzerinde bir tesir yarattığını gören Yahudi hekimler, 'bizim bildiğimiz dille konuş; ne diye bilmediğin dille söylüyorsun, söylediklerini Türklerin anladı̆̆ını mı sanıyorsun?' dediler... Dediklerimi anlayıp anlamadıklarını sordum. Hepsi evet dediler. Süt misali, paşanın da öbürlerin de pek hoşlarına gitmişti. Ve hepsi bana hak verdiler." (Carım, 1964, s.41).

\section{Berberlerin Tedavideki Yeri}

Popüler tarihçiliğimizin önde gelen isimlerinden olan Reșat Ekrem Koçu, berber sözcüğüyle ilgili olarak şu açiklamada bulunur. "Garb Türkçesine Italyancadan girmiş bir kelimedir, 'barbiere'den bozmadır; sakal kesen mânâsında ise de saç ve sakal kesen ve düzelten esnafa verilmiş isimdir; arabcası 'hallâk'tır.” Koçu, İstanbul'un fethinden Kanuni Sultan Süleyman zamanında kahve keyfinin yayılmasına ve büyükşehirde ilk kahvehanelerin açılmasına kadar berber dükkanlarının nasıl bir yer olduğuyla ilgili bilgiye sahip olmadığımızı söyler (Koçu, 1961, s.2513-2514).

Uğur Aktaş da Koçu gibi Osmanlı döneminde Kanuni Sultan Süleyman'a kadar berberlerle ilgili herhangi bir kaydın olmadığını belirttikten sonra kahvenin gelmesiyle birlikte İstanbul'da kahvehanelerin açılmaya başladığını ve seyyar olarak gezen berberlerin yavaş yavaş kahvehanelerin bir köşesinde çalıştıklarını ifade eder. Aktaş, IV. Murad döneminde tütün ve kahvenin yasaklanması nedeniyle berberlerin eskiden olduğu gibi seyyar olarak çalıştı̆̆ını ancak IV. Murat'ın ölümüyle birlikte tekrar kahvehanelere dönen berberlerin kahveci esnafina yamak sayıldığını aktarır (Aktaş, 2010).

İstanbul'un Bizans dönemi berberleriyle ilgili verilen bilgilerde birkaç husus özelikle dikkat çekicidir. Berberliğin bir efsanesi mevcuttur. Aktaş, yoksul bir kasabın (Hesperos) yüzünde yara çıkan avukatı tıraş etmek zorunda kaldığını ve bu tıraşta usturaya benzer bir bıçak kullandığını söyler. Kasap bu tıraştan aldığı bahşişle kilisenin yanına bir berber dükkânı açmıştır. Manastır mensuplarının saç kesiminin tepesinin açık olması, her manastırda bir berberin olduğunun kanıtı sayılabilir. (Aktaş, 2010). Koçu, İslam inancında bunun yerini berberlerin Piri Hazreti Peygamberi tıraş eden Selman-1 Pâk'ın aldığını belirtir (Koçu, 1961).

$\mathrm{Bu}$ bilgiler 1şı̆̆ında berberliğin dinî kimlik ve ritüellerle ilişkili bir meslek olduğunu söyleyebiliriz. Çünkü Bizans'ta manastır mensubunun saçı tepesi açık biçimde tıraş edilirken Osmanlı'da ise dervişin sakalı uygun biçimde perdahlanır. Bizansta kendilerine parfüm dükkânlarında yer bulan berberler Osmanlıda kahvehanede sanatlarını icra ederler.

Koçu, eski berberlerin aynı zamanda sünnetçi, dişçi ve hacamatçı olduğunu kellik, uyuz, sıraca, egzama gibi cilt hastalıkları için ilaçlar ve merhemler hazırladıklarını bildirir (Koçu, 1961). Abdülaziz Bey, berlerlerin bu yönüyle memleketin cerrahlık görevini de icra ettiklerini belirtir (Arısan ve Günay, 2000).

Sadık Müfit Bilge, ordunun sefere çıktığında berberlerin de peştemalcı, hamamcı, tellak ve usturacı esnafı gibi diğer esnafla birlikte sefere katıldığını, çadırlarını yanlarında götüren berberlerin askerleri tıraş ve tedavi ettiğini belirtmiştir (Bilge, s.192). Mesela III. Ahmed devrinde Şark Seferine iştirak edeceğini gösteren vesikada "Hirfet-i Berberan"a rastlanmıştır. Bunlar sefere altı çadır ile iştirak etmiş ve diğer esnaflarla kıyaslandığında çadır sayısı en fazla olan berberler olmuştur. Yine sefer için berber esnafindan 36000 akçe toplanmış, nalbant ve çuhacı esnafından sonra sefere en çok katkı berlerlerden olmuştur (Aktepe, 1954). Bu vesika, berber esnafının devrindeki önemini ve mali gücünü göstermesi bakımdan dikkate değerdir. 
18. yüzyıla ait kimi belgelerde Osmanlı İmparatorluğunda berber esnafinın çalışma düzeni kimi esaslara bağlanmıştır. 1748 tarihli İstanbul Ahkâm Defteri'nde Edirne'deki berber esnafının İstanbul'daki berber esnafının nizamına uygun çalışması gerektiği bildirilmiştir (Ahkâm Defteri 1, s.56). 1764 tarihli İstanbul Ahkâm Defteri’nde ise esnafın çalışma düzeni ile ilgili bir nizamnamede Hasköy'de kaç tane berber dükkânı olacağı ve bunların nizamına dair hüküm verilmiştir (Ahkam Defteri 2, s. 22).

Bilge, berberlerin ve kullandıkları malzemelerin Osmanlı divan ve halk edebiyatının mecazlar dünyasında yer aldığını belirtmiş, divan şiirinde Bosnalı Sabit'in yazdığı Berber-nâme'yi, halk şiirinde ise Berber Destanı'nı örnek olarak vermiştir (Bilge, s.201-202). Mehmet Akif Ersoy'un Mahalle Kahvesi şiiri de berberlerin 20. yüzyılda edebiyatımıza yansıyan yönünü örneklendirmesi bakımından dikkate değerdir.

"Duvarda eski ocaklar kadar geniş bir oyuk, İçinde camlı dolap var ya, raflarında ne yok!

Birinci katta sülük beslenen büyük kavanoz;

Onun yanında kan almak için beş on boynuz.

İkinci katta bütün kerpetenler, usturalar...

Demek ki kahveci hem diş tabibi, hem perukâr!” (Ersoy, 2013, s.104).

Berberin sünnetçiliğinin çağdaş edebiyata iyi bir yansımasını da Mithat Enç'in "Berber Hüseyn" hikâyesinde buluruz. Yakın zamana kadar hatıralarda yaşayan bir olgudur (Enç, 1997, s.5867). Söz konusu çalışmamızda da Pedro'nun berberlere ait bu görevlerden bazılarını icra ettiğini görürüz.

"Sabahları kuleden çıkıp Sinan Paşa'yı ziyarete giderken her çağrıldı̆̆ım yere uğramaya kalkışsaydım konağa ancak gecenin geç saatlerinde varabilirdim. Kuledeki hastaları berberlere havale ediyor ve slyrllyyordum." (Carım, 1964, s.39).

"Hıdrellez günü Sinan Paşa’nın konağındaki kadınların kan aldırmak için bana hediye ettikleri gömlek ve mendiller bir yıllık ihtiyacımı karşılardı. O gün, yanıma iki berber alarak konağa gider; kadınlar örtülü olarak ikişer ikişer yanıma gelir ve yerlere veya bir tekneye bol bol kan akardl. Kipırdamasınlar diye kollarını ben tutup ovalar ve berberler hacamat ederdi." (Carım, 1964, s.144).

\section{Nabız Yoluyla Hastalıkların Teșhisi}

Osman Şevki Uludağ, o dönemde muayenenin basit olduğunu, hastanın yüzüne bakarak nabız kontrolüyle muayenenin gerçekleştiğini, bunu bilmenin bütün tabipler için gerekli olduğunu anlatmıştır. Nabzın durumunun dört unsura göre değiştiğini ifade eden Uludağ, "Birçok hastalığın teşhisinde yalnız nabza bakmakla, hastalık hakkinda yeterli bir kanaate varlliyordu. Nabzın hızlı atışı hararete, yavaş atışı soğukluğa, vüsati (genişliği) rutubete ve vücutta cerahat çokluğuna, normal atışı yubuset (kuruluğa) ve vücutta cerahat yokluğuna, münfahas (içyüzünü araştırma) bulunması, hararet azlığına, parmaklara tok tok dokunması nabzı ölçülenin bedeninin kuvvetine delalet ederdi." demiştir. (Uludağ, 1991, s.42-43).

18. yüzyılda hekimbaşı olan Gevrekzâde Hâfız Hasan Efendi'nin kadın ve çocuk hastalıklarını konu alan eserinde (Netîcetü'l-Fikriyye fî̀ Tedbîri Velâdeti'l-Bikriyye) de nabızdan muayene sayesinde hamileliği teşhis etmenin mümkün olabileceği söylenmiştir. Tabi ki bu, her hekimin harc1 olmayıp sadece usta hekimlerin koyabileceği bir teşhistir. ${ }^{3}$ Pedro'nun hastalık teşhisinde en çok başvurduğu yol, hastanın nabzına bakmaktır.

"Cerrah misin diye sorduklar... Durmuş Reis, 'Idrar ve nabız hekimidir, cerrahtan daha faydalıdır', dedi. Kürekten işte bu suretle kurtuldum.” (Carım, 1964, s.11).

"Bir gün bana hasta bir Türk'ü getirdiler. Hâline bakıp nabzını yoklayınca "geceyi geçirmez", dedim. "Bu hayvanın bir şeyden çaktı̆̆ yok, çağırın berberi”, dediler. Geminin Hristiyan olan Portekizli berberi geldi. Önce benim ne söylediğimi ögrenmek istedi. Geceyi geçiremez, diye,

3 Gevrekzâde Hâfız Hasan, Netîcetü'l-Fikriyye fî̀ Tedbîri Velâdeti'l-Bikriyye, İstanbul Üniversitesi Kütüphanesi, Türkçe Yazmalar, No:7092, vr. 23a(5-6). 
tekrarladım ve bilgiçlik satmak için de "nabzı nasıl attığını duymuyor musun, vücudu buz kesilmiş, kımıldamaya bile gücü yok, dili pas içinde, betbeniz kalmamış, ölüye dönmüş", gibi hikmetler savurdum. Berber, "Allah'in izniyle, ben iyi ederim”, demesin mi?" (Carım, 1964, s.15).

"Yanına vardiğımda, makamında bayağı bir kral gibi oturan paşa, şu ve bu rahatsızlikları geçiren bir kadın için beni çağarttı̆̆ını söyledi. Bir kere görelim, gereğini yaparız, dedim. Görmek olamaz deyince, ben de idrar ve nabız yoklamasına girişmeksizin hiçbir şey yapamayacă̆ımı kesin olarak anlattım." (Carım, 1964, s.35).

"Paşa bayıldı̆̆ zaman, öldü diye ortalık bir çalkalandl. Ev halkl, köşsede bucakta, ağlamaya başladı. Yanına ben koştum, nabzını yokladım, rakı istedim ve iki ufak kahve kaşığı içirdim." (Carım, 1964, s.44).

\section{Kan Aldırmanın (Hacâmat) Sağlığa Etkisi}

Bir tabibin mutlaka kan almayı bilmesinin şart olduğunu öne süren Uludağ, kan almanın çoğu hastalık için başvurulan bir tedbir olduğunu belirtmiştir (Uludağ, 1991, s.44). Mossensohn ise, kan almanın 19. yüzyıla kadar yaygın olarak başvurulan tıbbi bir uygulama olduğunu, Hz. Muhammed'in bu tür bir tedaviye onay verdiğini ve hatta kendisinin de bu işlemi yaptırmasının kan almaya ilave bir meşrutiyet kazandırdığını bildirmiştir. Kan aldırmanın çeşitli ağrı ve sızılar için rutin bir tıbbi tedavi olmasının yanında önleyici tıp olarak saraydaki hayat tarzının bir parçası olduğunu söylemiştir (Mossensohn, 2014).

Abdülaziz Bey, kan aldırmayla ilgili şu açıklamada bulunmuştur. "Săğlk kurallarının en önde gelenlerinden biri de mayls ayında herkesin mutlaka ya kan aldırmasi ya hacamat ettirmesi veyahut sülük tutturmasıydl. Çok eski zamanlardan beri süregelen inanışa göre yaz başlarında kan eskimiş ve koyulaşmış olurdu, bu yüzden kanın yenilenmesi için kan aldırılmass gerekliydi. Bu işi yapmasını bilenler, belirli dükkânlarda otururlardı. Bunların esas mesleği berberlikti." (Arısan ve Günay, 2000, s.350).

Bunun yanında Leyla Saz'ın anılarının toplandığı kitapta, o dönemde bile özellikle mayıs ayının damarları boşaltmak (fazla ve zehirli kanı) için en uygun ay olarak seçildiğini, nişter ve sülük vasıtasıyla bu işlemin gerçekleştiğini öğrenebiliriz (Borak, 2004). Leyla Saz, hekim olan babası sayesinde bu uygulamaları yerinde izleme imkânı bulmuştur. Pedro'nun hatıratında da kan aldırma geleneğinin uygulanmış olduğunu görürüz.

"Sinan Paşa, dev yapıll, cidden yaklşıklı ve pek yiğit bir adamdl; çok da kanlıydl. Bir gün kollarından, iki defada iki libre kan aldıydım; pek memnun kalmıştı. Ertesi gün, bunu duyan ve Paşa'yı tırtıklamağa alışmış bulunan Yahudi bir hekim konağa koştu. Yahudi hekimler, kan almaktan çekinirler. Paşa, kan aldırmak ve her gün bal şerbeti içmek sayesinde, iyileşti ve iki yıl kadar artık kendisini öksürük tutmadı." (Carım, 1964, s.20-21).

"İsler anlattığım gibi yürürken, tutsakların arasında yumurcak patlak verdi. Hastalık, kaygısızlık yüzünden yayılarak, pek çok kişiyi serdi. Ben de tutuldum ve döşek olarak bir koyun postunun üzerinde eli gün yattıktan sonra kan aldırıp Tanrı'nın izniyle iyileştim.” (Carım, 1964, s.33).

"Dediklerimi Sultan, iki şart koşarak kabul etti: müsül almamak ve kan aldırmamak. Bu iki şeyi fazla tatbik ettiklerinden o hâle geldiğini anlattı. Olur dedim..." (Carım, 1964, s.37).

\section{Hekimlerin Güvenilir Olması}

"Osmanlı yönetimi açısından hekimlik, yalnızca günümüzde anladığımız anlamdaki tıbbi tanı ve tedaviyi sağlayan kişi anlamına gelmiyordu. "Hekime güven" kavramı padişah ve diğer devlet ileri gelenleri açısından aynı zamanda "hayati güven" anlamına geliyordu. Çünkü hayatların teslim ettikleri hekimlere güven duymalar ve onlardan kendilerine herhangi bir tehlike gelmemesi gerekiyordu." (Yetkin'den aktaran Aydın, 2006, s.204).

Saraydaki hekimlerin hem bilgili hem de güvenilir olmaları gerekiyordu ki bu, saraydakilerin can güvenliği için oldukça önemlidir. Kitaptaki kahramanımız Pedro, efendisi Sinan Paşa'nın güvenini öylesine kazanmıştır ki hekimliğinin yanı sıra tıpkı bir çaşnigîr gibi mutfağa inip efendisinin yiyeceği yemeklerin kontrolünü bile yapmıştır. Taneri, çaşnigîrin görevi ve seçimi konusunda şu açılamayı 
yapmıştır. "Ekâbir-i hâs denilen saray büyükleri arasında yer alan çaşnigîrin esas görevi, maiyetindekilerle birlikte sultanın sofrasın hazırlamak ve sofraya konulan yemekleri sultandan önce tatmak suretiyle onun zehirlenme ihtimalini önlemekti. Büyük Selçuklulardan itibaren çeşitli İslam devletlerinde rastlanan çaşnigîr hükümdarın en güvenilir emirleri arasından seçilirdi." (Taneri, 1993, s.232). Söz konusu kitapta, Sinan Paşa'nın Pedro’ya güveninin tam olduğunu söyleyebiliriz.

"Sinan Paşa'nın on iki yıldan beri çektiği nefes darlı̆̆ artmıştı. Göstermediği hekim kalmamıştı. Sonunda beni de çağırdılar. Paşa'ya elimle bir şurup hazırladım. Nasıl alınacağını sorunca işi çaktım ve bir kaşık isteyerek gözü önünde üç kere doldurup içtikten sonra "alsana senyor" diyerek kendisine de içirdim. Paşa pek memnun kaldl. Şurup tükenince Paşa'ya öksürü̈k hapları hazırladım ve beş hap gerekirken altı tane yaptım. Altısını da kendisine verdikten sonra bir tanesini isteyip yuttum. Paşa'nın bu da pek hoşuna gitti. Verdiğim ilaçlar iyi geldi ve Paşa düzelmeğe yüz tuttu." (Carım, 1964, s.19-20).

"Bir gün mutfağa girip (Yahudi) hekimlerin aşçıya Paşa'ya yemek olarak, bir pilicin yarısını yarım kâse suda haşlamasını ve tuzu piliç piştikten sonra atmasını tembih ettiklerini öğrendim. Derhal, kahpe oğullarl, alçak herifler, deyip ağzıma geleni veriştirerek ateşe dört tencere sürdürdüm. Tencerelere ikişer tavuk koydurarak birine nohut, birine maydanoz ve kereviz, birine soğan ve mercimek, birine de türlü zerzevat attırdım. Kızartmadan hoşlananlar için de ayrıca iki tavuk klzarttırdım. Olayı ögrenen Paşa nezdinde, itibarım arttı." (Carım, 1964, s.46).

\section{Saray Eşrafının Muayane Edilmesi}

Bayat, hanım sultanların hastalandıkları zaman muayene edilirken sultanın cariyelerinden birinin o ortamda bulunması gerektiğini ve hastanın baştan ayağa kıymetli ince bir top şal örtülerek ancak tüller üzerinden muayenenin gerçekleşebileceğini belirtmiştir (Bayat, 1999).

Mossensohn, saray eşrafının muayene edilişini ayrıntılı olarak şu şekilde aktarmıştır. " 17 . yüzyllın başında Venedik balyosu olarak iki buçuk yıl İstanbul'da bulunan Otaviano Bon, sarayın sakinlerine sunulan tıbbi hizmetlerin özünde barındırdiğg karmaşayı tasvir etmişstir. Haremdeki kadınlardan bir hastalandığında, tedavisi için bir hekim gönderiliyordu fakat bu, ancak evvela padişahın izni alındıktan sonra gerçekleşiyordu. Padişah hareme girmesine izin verince, hekim siyahi hadım ăgalardan biri tarafindan hastanin yanına götürülüyordu ancak bu sirada diğer hizmetçiler hekim tarafindan görülmemek için odasına çekiliyorlardı. Hasta, hekimin nabzını ölçebilmesi için açıkta bıraktığı bir kolu dışında başından ayağına kadar örtünüyordu. Bununla birlikte, valide sultan ya da padişahın hanımlarından veya cariyelerinden biri hastalanacak olursa, nabzı kontrol etmesi için hekime uzatılan kol ipekle örtülüyordu. Bir erkeğin bu kadınların çıplak tenine dokunmasl ve konuşmast yasakt.." (Mossensohn, 2014, s.191-192).

Görüldüğg̈ gibi seçkin kesimin hekimi olmak oldukça zordur, özellikle hanım sultanların hastalıklarının teşhis ve tedavisinde çok hassas olunması gerekir. Pedro'nun da saraydaki sultan ve cariyeleri muayene etmesi benzer şekilde olmuştur.

“Hastanın kocası Rüstem Paşa, efendim olan Sinan Paşa'nın kardeşiydi. Bir kere görelim gereğini yaparız, dedim. Görmek olamaz deyince ben de idrar ve nabız yoklamasına girişmeksizin hiç bir şey yapamayacağımı kesin olarak anlattım." (Carım, 1964, s.35).

"Hastanın döşeğine yaklaştı̆̆ım vakit, bir elinden başka her tarafinın sırma işlemeli bir çarşafla örtülü bulunduğunu gördüm. Uzatılan bir havluya ellerimi sildikten sonra nabzını yokladım. Kocasının bu kadarla yetinmemi istediğini sezdimse de aldırmadım ve tercümanın yardımına başvurmadan becerebildiğim kadar Türkçe geveleyerek "öbür elini de ver Sultan”, dedim. Açı bulunan eli çekip öbür eli çıkarırken beni gözetlemek için örtüyü biraz açtığını gören kocası, ben eli yoklar yoklamaz ayağa kalkarak "gidelim artık, oldu tek bir el bile yeterdi", dedi." (Carım, 1964, s.36).

"(Haremağası) kadınları kapattıktan sonra gelip beni hastanın odasına götürürdü. Sağa sola göz gezdirmeden papazlar gibi ayaklarımın ucuna bakarak girerdim. Bir süre böyle gitti. Sonunda Paşa'ya şikâyet ettim ve "Benden ne denli emin olabileceklerini Efendimiz bilir, o kötü zenci bana etmediğini bırakmiyor ve hastanın yüzünü göstermiyor, görmeyince de gereken tedaviye girişemiyorum" dedim. Paşa baktıklarım benden gizlenmesin ve bakarken başka kimse bulunmasın 
diye emir verdi. O günden sonra ve zenciye rağmen hastanın nabzın dilediğim gibi yoklar ve kan almak gerekirse hangi damarın daha elverişli olduğunu anlamak için kollarının ikisini de açtırırdım." (Carım, 1964, s.131-132).

\section{Hastanın Ölümüne Yaklaşımda İnancın Etkisi}

“Türkler (özellikle hastalık konusunda) her şeyin Allah'tan geldiğine inanırlar” deyişi, tipik bir oryantalist Batılı bakış açısıdır diyebiliriz. Çünkü dünden bugüne hekimlerin uygulamalarının şikâyet edildiğine dair pek çok belge mevcuttur. Örneğin Sadık Müfit Bilge, hacamatçı, dişçi ve sünnetçilere açılan davalarla ilgili kayıtlara 16. yüzyıldan itibaren rastlandığını belirtmiştir (Bilge, s.194).

Tahsin Özcan berberlerin yanlış uygulamaları sonrasında yapılan şikâyetlerin hükme bağlandığını fetvalarla örneklendirmiştir. Mesela bir berberin, bir hastanın dilinin altındaki damardan kan alırken damarını gereğinden fazla kestiği için kişi, hastalanıp ölmüştür. Olay üzerine vârisleri diyet talebinde bulunmuş ve neticede berberin diyet vermesine dair hüküm verilmiştir. Yine bir başka olay, berberin çürük diş yerine sağlam bir dişi çekmesi üzerine yaşanmıştır. Bu olayda da berberin diyet ödenmesine karar verilmiştir. Kölenin sünnet edilmesiyle ilgili bir başka fetvada da hatalı sünnet nedeniyle kölenin erkekliğinin zail olmasına sebep olan berberin söz konusu zararı tazmin etmesi hükme bağlanmıştır (Özcan, 2003, s. 185-186).

"Hasta o gece vücudunu denize ve canını da şeytana teslim etti. Bu olay dolayısı ile tanıştığım berber, bana, "Bundan sonra hastalara, hep şifa vaat et, Türkler Hristiyanlara benzemez, ölümü hiçbir vakit hekime yüklemezler, saati gelmiş göçtü, derler", dedi." (Carım, 1964, s.15).

"Türkler, hastalıklara karşı kendilerini korumazlar. Allah'tan gelen şeylerden kaçınılmaz derler." (Carım, 1964, s.34).

"Paşa mahkeme ilamı biçiminde dürülü ve mühürlü azad kâğıdımı uzattı. Ayağını öpmek için diz çökünce kolumdan tutup kaldırarak alnımdan öptü ve "Allah'tan başka hiç kimseye teşekküre borçlu değilsin, olup biten hep O'nun diledikleridir." (Carım, 1964, s.50).

\section{Sonuç}

Bu çalışmada Pedro'nun hatıralarında hekimlik ile ilgili kısmı değerlendirilmiştir. Bizlere "tıp ya da tıp tarihi" denildiğinde, genellikle aklımıza ilk gelen şey hekim ile hastadır. Onun sosyal bir hadise olduğu gerçeğini çoğu zaman gözden kaçırırız. Hastalık, hastalık ile mücadelede benimsenen yöntemler, tedaviler, uygulamalar toplumsal hayatımıza dair ciddi ipuçları barındırırlar. Çünkü tıbbın kendisi uzun süre insanların birbirlerine tecrübelerini aktarmaları ile var olmuştur. Tabi ki bu tecrübeler, bazı pratik uygulamalarla kimi inanış ve doğru bilinen yanlışlarla birlikte nesilden nesile aktarılmıştır. $\mathrm{Bu}$ da bize hekimliğin yanında tedavinin de bu yönüyle sosyal uğraşlar olduğunu göstermesi bakımından oldukça önemlidir. Bu sayede toplumsal hayatımıza dair bazı bilgilere ulaşabiliriz.

Pedro, bize atalarımızın nasıl tedavi olduklarına dair bilgiler verip örnekler sunmuştur. Belki buradaki kişiler (diyaloglardaki üç kişi) gerçek kişiler değildir, ancak anlatılan olaylardaki bilgilerin kaynaklarda geçen bilgilerle örtüşmesi bu hikâyenin gerçekliğini ortaya koymaktadır. Fuat Carım da kitabın ön sözünde buradaki bilgilerin okumak ve işitmekle öğrenilen bilgilere dayanamayacağını açıklamıştır. Tabi bu hatıralar, hekimlik dışında başka hususlarda da değerli bilgiler sunmaktadır. Söz gelimi yeme içme âdet ve alışkanlığının zaman içerisindeki değişimini gözlemleyebilmemizi sağlar. Onun verdiği bilgiye göre büyük bir devlet adamı olan Sinan Paşa sofrada çok hızlı bir biçimde yemek yiyip kalkınca sofra, bekleyenlere bırakılmıştır. Önemsiz bir ayrıntı gibi söz ettiğimiz bu konu, o dönemin atmosferiyle ilgili bir ipucu vermektedir. Farklı bir bakış açısıyla baktığımızda "Sinan Paşa gibi birinin konağında niçin debdebeli sofralar kurulmamış ve neden her öğün şölen atmosferinde geçmemiştir?" soruları aklımızı kurcalar ve biz ziyafet sofralarının ne zaman kurulmaya başladığı sorusunu düşünürüz. Oysa bu sorunun cevabını Osmanlının klasik devrinden sonra yani dağılma, çökme döneminde arayabiliriz. $\mathrm{Bu}$, bizi şu sonuca ulaştırabilir; çöküntü arttıkça debdebe fazlalaşmaktadır. Bir hatırat kitabından ve yemek gibi gündelik bir ayrıntıdan yola çıkarak önemli saptamalarda bulunulabilinir. İşte Pedro'nun hatıralarının bize tam olarak kazandırdığ 
Çünkü önemsiz gibi görünen bu ayrıntılar, bizlere resmi biraz daha büyütmemiz için şahane olanaklar sunmaktadir.

\section{Kaynaklar}

Abdülaziz Bey, (2000). Osmanlı âdet, merasim ve tabirleri, (Yay. haz.) Arısan, K. ve Arısan Günay, D. İstanbul: Tarih Vakfi Yurt Yayınları.

Aktaş, U. (2010). İstanbul'un 100 esnafi, İstanbul: İstanbul Büyükşehir Belediyesi Kültür Yayınları.

Aktepe, M. M. (1954). Ahmed III. devrinde şark seferine iştirâk edecek ordu esnafı hakkında vesikalar, Tarih Dergisi, 7(10), 17-23, İstanbul: Osman Yalçın Matbaası,

Aydın, E. (2006). Dünya ve türk tıp tarihi, Ankara: Güneş Kitabevi.

Bahadır, Ş. D. (2016). Gevrekzâde Hâfiz Hasan Efendi'nin Netîcetü'l-Fikriyye fî Tedbîri Velâdeti'lBikriyye adl eseri (inceleme-metin-dizin). Yayımlanmamış Doktora Tezi. Erciyes Üniversitesi Sosyal Bilimler Enstitüsü, Kayseri.

Bayat, A. H. (1999). Osmanlı devleti'nde hekimbaşılık kurumu ve hekimbaşılar, Ankara: Atatürk Kültür Merkezi Başkanlığı Yayınları,.

Bilge, S. M. (?). Osmanlı İstanbul'unda berber esnafi. Osmanlı İstanbul'u 2, s.187-206.

Borak, S. (2004) Harem 'in iç yüzü Leyla Saz'ın anıları, İstanbul: Kırmızı Beyaz Yayınları.

Carım, F. (1964). Kanunî devrinde İstanbul. İstanbul.

Carım F. (2002). Pedro ’nun Zorunlu İstanbul Seyahati. İstanbul: Güncel Yayıncılık.

Demirören, Y. (2011) Türkiye seyahati Kanuni Sultan Süleyman devrinde İstanbul (1557 yılında bir el yazmast), Erko-Tarihi Araştırma Dizisi, İstanbul.

Ersoy, M. A. (2013). Safahat, Ankara: Türkiye Diyanet Vakfı Yayınları.

Hazard, P. (1996). Batı düşüncesindeki büyük değişme, (Çev.) Erol Güngör. İstanbul: Ötüken Neşriyat.

Kal'a, A. (1997). İstanbul ahkâm defterleri/İstanbul esnaf tarihi 1. (Yay. haz.) Tabakoğlu A., Aynural S., Kara İ., ve Kal'a E.S. Cilt 1, s.56, İstanbul: İstanbul Büyükşehir Belediyesi Kültür İşleri Daire Başkanlığı İstanbul Araştırmaları Merkezi Yayınları.

Kal'a, A. (1998). İstanbul ahkâm defterleri/İstanbul esnaf tarihi 2(Yay. haz.) Tabakoğlu A., Aynural S., Kara İ., ve Kal'a E.S. Cilt 8, s.22, İstanbul: İstanbul Büyükşsehir Belediyesi Kültür İşleri Daire Başkanlığı İstanbul Araştırmaları Merkezi Yayınları.

Koçu, R. E. (1961). İstanbul ansiklopedisi, Cilt 5, s.2513-2520, İstanbul.

Mossensohn, M. S. (2014). Osmanlı tıbbı tedavi ve tıbbi kurumlar 1500-1700, (Çev.) Bülent Üçpunar. İstanbul: Kitap Yayınevi.

Önalp, E. (1990). Bir ispanyol esiri gözüyle 1552-1556 yılları arasında istanbul. Ankara Üniversitesi Osmanlı Tarihi Araştırma ve Uygulama Merkezi Dergisi, s.313-320, Ankara.

Özcan, T. (2003). Fetvalar ışığında osmanlı esnafi. İstanbul: Kitabevi Yayınları.

Refik, A. (1998). Lady Montagu Şark Mektupları, (Yay. haz.) Gürlek, D.. Timaş Yayınları, İstanbul.

Şehsuvaroğlu, B., Demirhan A. E. ve Güreşsever, G. C. (1984). Türk tıp tarihi, Bursa: Taş Kitapç1lık. 
Taneri, A. (1993). "Çaşnigîr”, Türkiye diyanet vakfi islam ansiklopedisi, Cilt 8, s.232, İstanbul.

Uludağ, O. Ş. (1991). Beş buçuk asırlık türk tababeti tarihi, (Yay. haz.) Uzel, İ. Ankara: Kültür Bakanlığı Yayınları.

Uludağ, O. Ş. (2010). Osmanlılar devrinde Türk hekimliği, Ankara: Türk Tarih Kurumu Yayınları. 


\section{Extended Abstract}

This piece brought in our culture by Fuat Carım describes the events a person, who had been taken to Istanbul as a captive in the era of Suleiman the Magnificent, experienced. The present study involves those mentioned about medicine and treatment, but not the whole piece. Pedro, the narrator of analyzed piece, was an open-minded person. Those he narrated are a good example of travel literature. Of course, he gives information about illness, medicine, and treatment that are the study's particular interest, in addition to the topics such as traditions, customs, and religions.

The book, translated by Fuat Carım firstly into French was translated into Turkish in 1964. Carım translated some parts of the book's first chapter and the whole second chapter in that translation. In the first chapter, it was narrated the events Pedro experienced while he was captive; the organization in Turkey and the customs of people in Istanbul were described in the second chapter. Especially the headings in the first chapter were added by Carım. The information in the parentheses was also explained by Carım.

The book is comprised of the dialogues between three people (Pedro de Urdemalas, Juan de Voto a Dios ve Matalas Callando). The person called Pedro was taken to Istanbul by being captured by the navy at Sinan Pacha's command in the era of Suleiman the Magnificent. He reported the events that he had witnessed there, in dialogues. Those told by Pedro regarding the medical practices are confirmed by historical sources.

The topic is assessed under the headings such as "Pedro's Release from Captivity and Medicine Learning Process, Role of Barbers in Treatment, Diagnosis of Illnesses by Pulse, Effect of Blood Donation (Hijama in Islamic term) on Health, Credibility of Doctors, Medical Examination of Palace Notables, and Effect of Faith on the Approach toward Patient's Death. The comparison of examples given about the treatment and diagnosis methods of illnesses with the information in resources would demonstrate whether the information is consistent or not.

Pedro's Release from Captivity and Medicine Learning Process: It occurred thanks to an old captive who had converted to Islam before. Pedro said that he became a doctor on the captive's advice. Pedro should be regarded as an exception although he became the doctor of Sinan Pacha by reading the book he had obtained without having medical education.

Role of Barbers in Treatment: Those told about barbers are also related to medicine because the barbers in ancient times were sometimes surgeon, dentist other times. Moreover, they had the duties like drawing blood and preparing cure and ointment for dermatological illnesses such as alopecia, scrofula, mange, eczema. It was detected in the text that Pedro had fulfilled some of those duties.

Diagnosis of Illnesses by Pulse: at that time, the most effective method in diagnosing illnesses is to take patient's pulse. Also, it was required for all doctors to be familiar with it. The method Pedro has used most is to take patient's pulse.

Effect of Blood Donation (Hijama in Islamic term) on Health: A doctor had to be familiar with drawing blood. This operation was considered to be a precaution against many illnesses since it was believed that one can get rid of toxic blood only by that way. It can be seen at Pedro's memoirs that the custom of blood donation was practiced.

Credibility of Doctors: it is required that the doctors in the palace were both credible and wellinformed. This was so important for life safety of ones in the palace. Pedro, the main character in the book, had gained his master's, Sinan Pacha's, trust. Even, he had entered the kitchen and checked the dishes his master would eat like a taster.

Medical Examination of Palace Notables: the examination of palace notables was far from commonness, it had to be carried out in a certain manner. It was required to be careful particularly in diagnosing and treating the illnesses of sultanas. It was impossible to touch their skin and see their body completely. The examination of sultanas and odalisque in the palace by Pedro was likewise.

Effect of Faith on the Approach toward Patient's Death: It was explained in the book that Turkish people did not use to hold doctor responsible for disease related death because they believe that 
everything comes from Allah. Pedro had made that mistake and said that the patient would die. However he had never repeated that mistake.

In this study, the part about medicine in pedro's memoirs was assessed. Illness and methods for fighting against illness, treatments, practices involve significant clues about our social life. Because, medicine has existed by people transferring their experiences to each other for a long time. These experiences were passed down with some practices, beliefs, and false facts. By this way, we can reach certain information about our social life.

Pedro gave us information about how our ancestors were treated and examples on it. The people there (three people in dialogues) may not be real but the consistency of information told in the events with the information in resources reveals the reality of that story. Fuat Carım explained in his book's preface that that information cannot be relied on the information learned orally or by reading. Those memoirs offer important information about certain issues other than medicine. 